\title{
Polyostotic Fibrous Dysplasia: A Case Report
}

\author{
Vikram Khanna* and Akhil Shori \\ Department of Orthopaedics, ERA's Lucknow Medical College, India
}

Submission: February 4, 2017 ; Published: May 20, 2017

*Corresponding author: Department of Orthopaedics, ERA's Lucknow Medical College, Lucknow, India Tel: +91 7073647974;

Email: 86.khanna@gmail.com

\begin{abstract}
Introduction: Fibrous dysplasia is a relatively rare condition characterized by fibrous tissue replacement of the skeleton. It may implicate one or several bones and favors one side of the body. It begins in childhood and may progress beyond puberty and adulthood. Both sexes are equally affected.

Case study: A 25 year old female presented with fracture in right femur after a trivial trauma. X-ray showed multiple multilocular cystic lesions with ground glass diffuse rarefactions throughout the bone with mid shaft transverse fracture. Similar lesions were seen in B/L Proximal humerus and Rt pelvis. Base of the skull showed Hyperostotic Bone formation. Bone Biopsy showed the mesenchymal stroma surrounding the dysplastic trabeculae is relatively hypocellular. There is a lack of osteoblastic rimming surrounding the dysplastic trabeculae. Both features are characteristic of fibrous dysplasia. The patient was managed with bisphosphonates and Thomas knee splint and union was seen in 2 months.
\end{abstract}

Keywords: Fibrous dysplasia; polyostotic; Ground glass; Shepherd crook deformity; GNAS1 gene

\section{Introduction}

Fibrous dysplasia is a condition leading to abnormal differentiation of osteoblasts which leads to replacement of normal bone with fibrous stroma [1-3]. It may involve single bone (monostotic) or multiple bones (polyostotic). It may affect any bone however; skull and ribs are the commonest [2,4-6]. It is usually asymptomatic and is an incidental finding. It may become symptomatic when complicated by pathologic fracture or malignant change. It may be associated with aneurysmal bone cysts [6-12]. The mechanism of occurrence of $A B C$ with Fibrous dysplasia is not known but it may be said that there may be a secondary disruption of osseous supply caused by the fibrous dysplasia leading to $\mathrm{ABC}$. This association of $\mathrm{ABC}$ with fibrous dysplasia may lead to rapidly increase in growth which may be confused with malignant change $[5,10]$. We report a case of polyostotic Fibrous dysplasia in a 26-year-old lady showing the characteristic changes.

\section{Case Report}

A 26 year old female presented with fracture mid shaft of left femur after having a trivial trauma. Patient had previous history of fracture in the right femur 4 years back presiding with limp and pain in right thigh.

\section{On examination}
a) Anterior bowing of lt. thigh was seen.
b) Swelling in the mid-thigh region $4 \times 8 \mathrm{~cm}$
c) Bony crepitus was present.
d) Peripheral neurovascular status was normal.

\section{On x-ray}

a) Multiple multilocular cystic lesions with ground glass diffuse rarefactions throughout the bone with mid shaft transverse fracture.

b) Similar lesions were seen in B/L Proximal humerus and Rt pelvis.

c) Overlying cortex was thinned and expanded with thickened medial cortex with a typical 'Shepard's Crook Deformity' due to varus deformity of the neck.

d) Base of the skull showed Hyperostotic Bone formation.

\section{Bone biopsy}

I. The mesenchymal stroma surrounding the dysplastic trabeculae is relatively hypocellular. There was a lack of 
osteoblastic rimming surrounding the dysplastic trabeculae. Both features are characteristic of fibrous dysplasia.

II. A field of mature hyaline cartilage is shown adjacent to a bland fibrous stroma.

\section{Lab reports}
i. $\quad$ Hb. $=9.6 \mathrm{~g} / \mathrm{dl}$
ii. $\quad$ TLC $=9000$ cells $/ \mathrm{ml}$
iii. $\quad \mathrm{DLC}=\mathrm{n}=60 \mathrm{l}=15 \mathrm{~m}=1 \mathrm{e}=0 \mathrm{~b}=0$
iv. $\mathrm{Sr} \mathrm{Ca}=9 \mathrm{mg} / \mathrm{dl}$
v. $S r$ alp $=60 \mathrm{iu} / \mathrm{l}$
vi. $\quad$ Sr phosphorus $=3 \mathrm{mg} / \mathrm{dl}$
vii. $\mathrm{T} 3=160 \mathrm{ng} / \mathrm{dl}$
viii. $\mathrm{T} 4=8 \mathrm{micro} \mathrm{g} / \mathrm{d}$
ix. $\quad \mathrm{TSH}=3 \mathrm{micro} \mathrm{U} / \mathrm{ml}$

\section{Management}

We treated our patient with zolindronic acid at time of presentation and at 3 months of the first injection. The patient was also kept on Thomas Knee splint for 2 months following which the fracture united and the patient was started with weight bearing ambulation.

\section{Discussion}

Fibrous dysplasia is a benign condition which was initially described by Lichtenstein in 1938 and Jaffe in 1942. It is a relatively uncommon condition with $0.8 \%$ primary and $7 \%$ benign bone lesions. It is monostotic in $70-80 \%$ of cases and polyostotic in $20-30 \%$ of cases. The age of presentation ranges from 10-70 years with the majority of cases (75\%) presenting before the age of 30 years [1,3-5,8,9,11,12]. It is associated with postzygotic-activating mutations of signal-transducing $G$ proteins encoded by GNAS1 on chromosome 20. Osteoblasts with this mutation had an increase in the proliferation and faulty differentiation leading to fibrotic bone matrix $[2,4,7,9,13]$. Fibrous dysplasia when polyostotic may be associated with McCune-Albright syndrome and Mazabraud's syndrome [2,5,14]. Polyostotic Fibrous dysplasia is more extensive and aggressive as compared to the monostotic lesions. These lesions generally progress till skeletal maturity and then become quiescent $[4,8]$. Monostotic lesions never transform into a polyostotic lesion. The disease generally becomes inactive after puberty $[6,14]$.

The gross histological picture of fibrous dysplasia constitutes a firm solid grey-white mass which gradually replaces the medullary cavity and the surrounding cortical bone. This lesion is generally well circumscribed and well differentiated from the host bone. It consists of uniformly cellular fibrous tissue with a proliferation of bland and uniform spindle cells with sparse mitotic activity. Some nests of woven bones are also present without any significant osteoblastic rimming. Some bony spicules are also present in the curvilinear, "Chinese alphabet" pattern. Sometimes, the woven bone may be deposited in sclerotic, interconnected lamellae, cementoid bodies, or in orderly and parallel spicules $[4,6,8,9,14]$.

X-rays features are not specific although they may be characteristic depending on the underlying histopathological picture. These features range from unilateral fusiform enlargement of medulla, deformity with cortical thickening, increased trabeculation to a characteristic "ground-glass" appearance which is formed by a mixture of immature bone and fibrous tissues [2,7]. On CT scan amorphous or irregular calcification may be seen. Magnetic resonance imaging maybe used in accurately defining full extent of the lesion.

Sudden increase in size of an existing fibrous dysplasia maybe due to superimposed $\mathrm{ABC}$ or malignant transformation $[6,10,12,14]$. Malignant transformation causes rapid increase in the size of the lesion but is rarely seen with an incidence of $0.5 \%$ in patients with monostotic FD. The incidence increases in patients with nearly $4 \%$ with McCune-Albright syndrome. It may develop after the involved bone getting irradiated. Most common malignant transformation is osteosarcoma followed by fibrosarcoma, chondrosarcoma and malignant fibrous histiocytoma $[2,4,6,7,9,11,14]$. Low grade osteosarcoma may mimic fibrous dysplasia. It maybe differentiated with the help of imaging and radiological features. Radiographic changes suggesting malignancy are lytic regions, intralesional calcification, periosteal reaction and a cortical disruption $[6,9,14]$.

Histologically, malignancy like low grade osteosarcoma will include atypical mitotically more active cells than fibrous dysplasia. Also, the regularly spaced spicules which are seen in fibrous dysplasia will not be seen in osteosarcoma which shows malignant osteoid deposited in broader and irregular trabeculae [9].

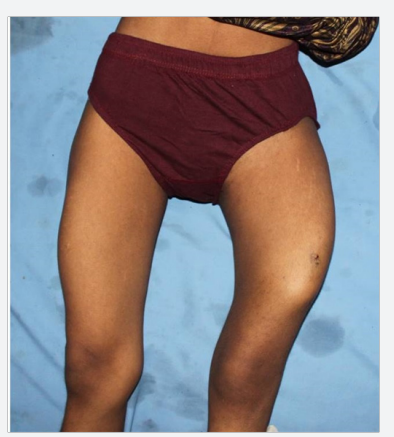

Figure 1: Clinical Picture showing bowing deformity of the left thigh. Patient had also got a fracture of left fracture femur due to trivial trauma.

Treatment of fibrous dysplasia for asymptomatic and stable lesions includes just monitoring of the patient. Surgery is only done for diagnostic biopsy, or to correct deformity, failure of 
non-surgical treatment prevention of pathological fractures and eradication of symptomatic patients. In polyostotic form bisphosphonate therapy may be used for the management and it leads to increase in the bone density and reduces the pain [3,4,7,13] (Figure 1-6).

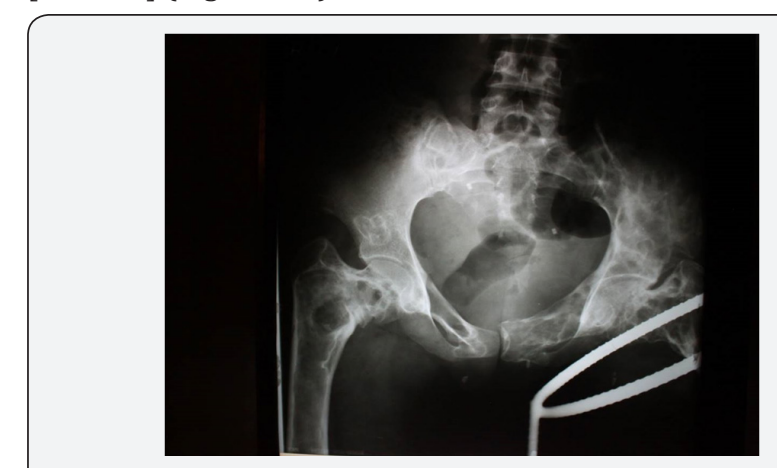

Figure 2: X-ray pelvis with both hip AP view shows expansile multiple lytic lesions involving pelvic bones and $B / L$ femur with Shepherd's crook deformity.

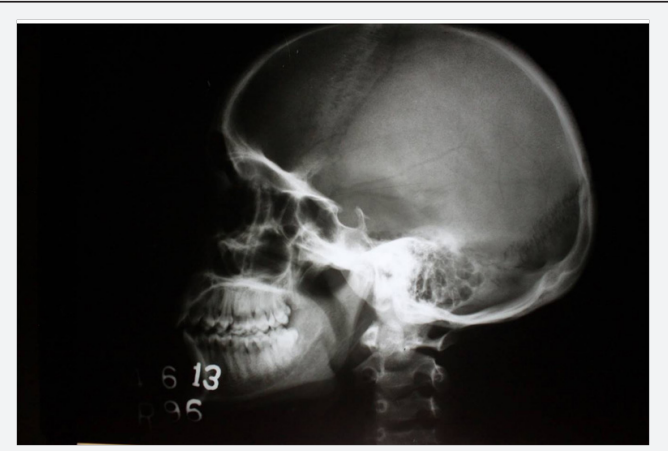

Figure 3: X-ray Skull shows ground glass appearance with sclerotic base.

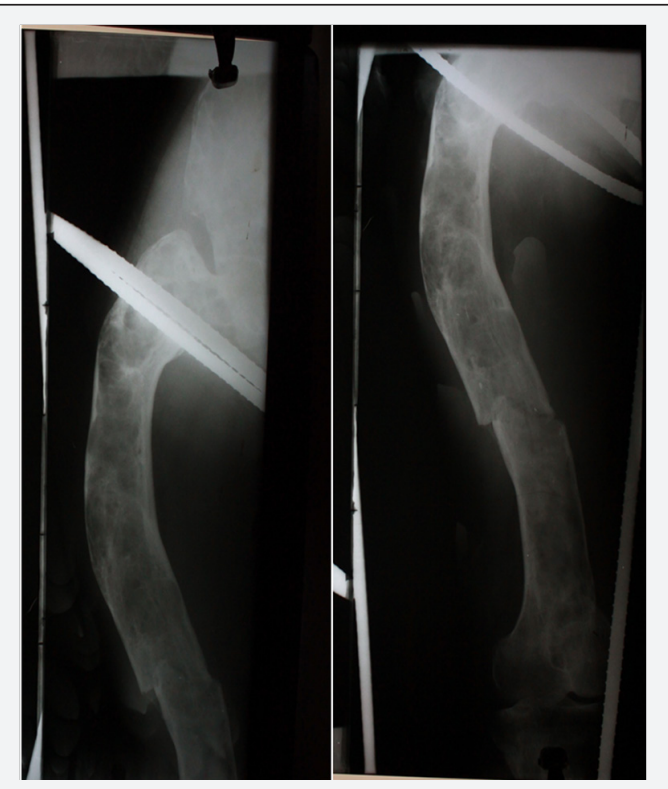

Figure 4: Multiple multilocular cystic lesions with ground glass diffuse rarefactions throughout the bone with mid shaft transverse fracture.

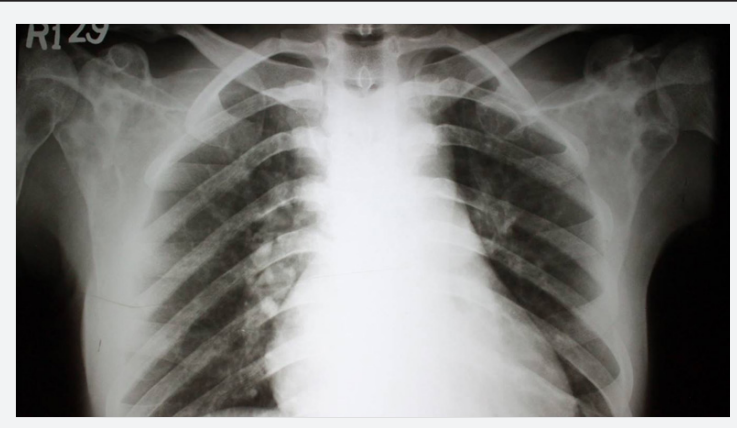

Figure 5: Multiloculated lesion in both the scapula along with haziness inn ribs seen.

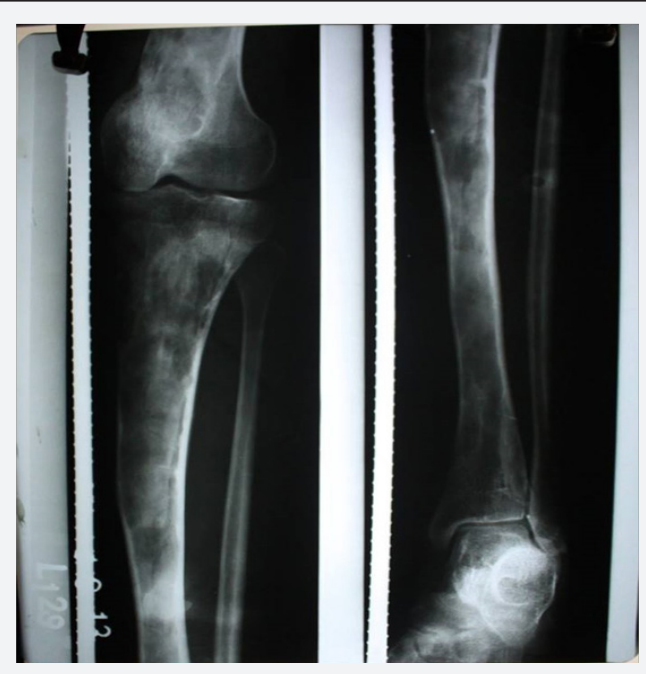

Figure 6: Ground glass appearance with multilocular cystic lesions in tibia.

\section{References}

1 A Henry (1969) Monostotic fibrous dysplasia. Journal of Bone and Joint Surgery B 51(2): 300-306.

2 FR Singer (1997) Fibrous dysplasia of bone: the bone lesion unmasked. Am J Pathol 151(6): 1511-1515.

3 Ayadi KA, Ben SS, Marghli A, Mehouachi R, Djilani H, et al. (2008) Fibrous dysplasia of the rib. Ten case reports, Revue de Chirurgie Orthopedique et Reparatrice de l'Appareil Moteur 94(3): 301-307.

4 Parekh SG, Donthineni RR, Ricchetti E, Lackman RD (2004) Fibrous dysplasia. J Am Acad Orthop Surg 12(5): 305-313.

5 Marieke NS, Folkert J van Kemenade, Barend J van Royen (2009) Monostotic fibrous dysplasia of a lumbar vertebral body with secondary aneurysmal bone cyst formation: a case report. Journal of Medical Case Reports 3(7227).

6 Shah ZK, Peh WC, Koh WL, Shek TW (2005) Magnetic resonance imaging appearances of fibrous dysplasia. Br J Radiol 78(936): 11041115.

7 A Traibi, FE Oueriachi, ME Hammoumi, EH Kabiri, AA Bouzidi (2012) Monostotic fibrous dysplasia of the ribs.Interactive Cardiovascular and Thoracic Surgery 14: 41-43.

8 Hughes EK, James SL, Butt S, Davies AM, Saifuddin A (2006) Benign primary tumours of the ribs. Clin Radiol 61(4): 314-322.

9 Fabrizio R, Frieda F (2012) Nonneoplastic lesions that simulate primary tumors of bone. Archives of Pathology \& Laboratory Medicine 136(7): 772-788. 
10 Diercks RL, Sauter AJ, Mallens WM (1986) Aneurys-mal bone cyst in association with fibrous dysplasia. A case report. J Bone Joint Surg Br 68(1): 144-146

11 Tateishi U, Gladish GW, Kusumoto M, Hasegawa T, Yokoyama R, et al. (2003) Chest wall tumors: radiologic findings and pathologic correlation: part 1. Benign tumors. Radiographics 23(6): 1477-1490.

12 Terkawi AS, Al-Qahtani KH, Baksh E, Soualmi L, Mohamed Ael-B, et al. (2011) Fibrous dysplasia and aneurysmal bone cyst of the skul base presenting with blindness: a report of a rare locally aggressive example. Head Neck Oncol 3(15).

13 Di Caprio MR, Enneking WF (2005) Fibrous dysplasia: pathophysiology, evaluation, and treatment. J Bone Joint Surg Am 87(8): 1848-1864.

14 Fitzpatrick KA, Taljanovic MS, Speer DP, Graham AR, Jacobson JA, et al (2004) Imaging findings of fibrous dysplasia with histopathologic and intra-operative correlation. AJR Am J Roentgenol 182(6): 1389-1398.

\section{Your next submission with Juniper Publishers will reach you the below assets}

- Quality Editorial service

- Swift Peer Review

- Reprints availability

- E-prints Service

- Manuscript Podcast for convenient understanding

- Global attainment for your research

- Manuscript accessibility in different formats

( Pdf, E-pub, Full Text, Audio)

- Unceasing customer service

Track the below URL for one-step submission

https://juniperpublishers.com/online-submission.php 